\title{
Electrochemical Analysis of Galena Reactivity in Typical Physicochemical Conditions of Calcareous Soils
}

\author{
G. Urbano ${ }^{1}$, V.E. Reyes ${ }^{1, *}$, M. A. Veloz ${ }^{1}$ and I. González ${ }^{2}$ \\ ${ }^{1}$ Área Académica de Ciencias de la Tierra y Materiales, Universidad Autónoma del Estado de Hidalgo, \\ Pachuca, Hidalgo 42184, México. \\ ${ }^{2}$ Área de Electroquímica, Departamento de Química, Universidad Autónoma Metropolitana - \\ Iztapalapa, Iztapalapa, D. F. 09340, México. \\ "E-mail: reyescruz16@yahoo.com
}

doi: $10.20964 / 110260$

Received: 3 December 2015 / Accepted: 4 January 2016 / Published: 1 April 2016

\begin{abstract}
A proposal methodology using electrochemical techniques and carbon paste electrodes (CPE) were applied to evaluate the oxidation mechanisms of galena and identify secondary species on its surface, in a medium that simulates typical physicochemical environment of the calcareous soils. This study was conducted at the larger interval of potentials, carried out beyond that data reported in the literature. The secondary species were observed with scanning electron microscopy technique. The results showed that with the proposed methodology was possible evaluate to quickly the oxidation mechanisms of galena due to instantaneous formation of secondary phases on the galena mineral surface and a simulated medium. Galena $(\mathrm{PbS})$ mineral is initially oxidized to sulfide intermediate species deficient in metal, followed by formation of a passive film of anglesite $\left(\mathrm{PbSO}_{4}\right)$. The subsequent formation of cerussite $\left(\mathrm{PbCO}_{3}\right)$ was carried out mainly by precipitation mechanism; meanwhile an electrochemical oxidation to cerussite occurs when the passive film of anglesite is dissolved from the galena surface. Finally, the formation of compact elongated structures with nanotubes shape was observed (likely phases of $\left.\mathrm{PbO}_{2}\right)$ to more positive potentials $\left(\mathrm{E}_{\lambda+} \geq 1.8 \mathrm{~V}\right.$ ).
\end{abstract}

Keywords: Galena mineral, electrochemical oxidation, calcareous soils, anglesite, cerussite.

\section{FULL TEXT}

(C) 2016 The Authors. Published by ESG (www.electrochemsci.org). This article is an open access article distributed under the terms and conditions of the Creative Commons Attribution license (http://creativecommons.org/licenses/by/4.0/). 